\title{
BAURAN PEMASARAN KERAJINAN CENDERAMATA BERBAHAN BAKU BAMBU BATIK (Studi Kasus Pada UD. Betris di Kelurahan Meras Kecamatan Bunaken Kota Manado)
}

\author{
Gita Syahfitri Labatjo \\ Agnes E. Loho \\ Lyndon R. J. Pangemanan
}

\begin{abstract}
This study aims to determine the marketing mix on UD.Betris. The research was conducted in November 2017 until January of 2018. The research method used is case study. Data used in this research are primary data and secondary data. The method of data analysis used is descriptive analysis that describes the implementation of marketing mix of Bamboo Batik Handicraft in Meras Village, Bunakaen Sub-district, Manado City. The result of the research concludes that marketing mix in general have good application in UD. Betris. Based on four aspects, only one aspect is a place that is not well implemented in UD. Betris because the place is not strategic yet.
\end{abstract}

Keywords: marketing mix, batik bamboo handicraft, UD. Betris, Meras Village, Bunaken Subdistrict, Manado City

\begin{abstract}
ABSTRAK
Penelitian ini bertujuan untuk mengetahui bauran pemasaran pada UD.Betris. Penelitian dilaksanakan pada bulan November 2017 sampai bulan Januari tahun 2018. Metode penelitian yang digunakan adalah studi kasus. Data yang digunakan dalam penelitian ini adalah data primer dan data sekunder. Metode analisis data yang digunakan adalah analisis deskriptif yakni mendeskripsikan pelaksanaan bauran pemasaran Kerajinan Bambu Batik di Kelurahan Meras Kecamatan Bunakaen Kota Manado. Hasil penelitian menyimpulkan Bauran pemasaran secara umum sudah baik penerapannya di UD. Betris. Berdasarkan empat aspek, hanya satu aspek yaitu tempat yang tidak baik penerapannya di UD. Betris karena tempatnya belum strategis.
\end{abstract}

Kata kunci: bauran pemasaran, kerajinan bambu batik, UD. Betris, Kelurahan Meras, Kecamatan Bunaken, Kota Manado

\section{PENDAHULUAN}

\section{Latar Belakang}

Indonesia merupakan negara yang mempunyai keanekaragaman hasil alam yang dapat digunakan untuk memenuhi kebutuhan hidup manusia. Namun demikian, kekayaan alam tersebut baru akan dapat memberikan nilai guna yang lebih banyak bagi masyarakat apabila diolah menjadi aneka macam produk. Salah satu pemanfaatannya adalah dengan pengolahan hasil alam menjadi barang kerajinan untuk meningkatkan nilai ekonominya. Di Sulawesi Utara mulai dikembangkan agroindustri berbahan baku bambu batik. Bambu batik adalah tanaman yang dapat tumbuh hingga ketinggian 15 meter, dengan diameter 4-8 cm. Bambu ini umumnya dipakai untuk membuat perabot kursi, meja atau bisa juga dibuat menjadi kerajinan tangan. Bambu ini juga dapat tumbuh baik di lahan kering dan tandus. 
Di Kelurahan Meras pada UD. Betris bambu batik telah diolah menjadi kerajinan tangan sebagai oleh-oleh khas Manado dengan bentuk dan model kerajinan seperti souvenir, kalung, gantungan kunci, bingkai foto, bunga, miniatur alat musik, miniatur rumah panggung dan lain - lain. UD. Betris merupakan satu satunya pengolahan bambu batik di Sulawesi Utara yang telah beroperasi selama 2 tahun, namun belum mempunyai landasan dalam memasarkan produknya. Pemasaran yang dilakukan UD. Betris masih dilakukan melalui pameran-pameran kerajinan tangan yang dilaksanakan oleh dinas atau pemerintah setempat serta menitipkan produknya di toko souvenier Miens dan Dekranas, sehingga perlu adanya suatu pengembangan strategi pemasaran selain melalui pameran-pameran tersebut. Strategi pemasaran merupakan upaya mencari posisi pemasaran yang menguntungkan dalam suatu industri atau arena fundamental persaingan berlangsung. Salah satu bentuk strategi pemasaran yang mampu mendukung dalam memasarkan produk adalah penggunaan bauran pemasaran (marketing mix).

\section{Konsep Pemasaran}

Basu \& Irawan dalam Utami (2016), mendefinisikan pemasaran sebagai sistem keseluruhan dari kegiatan usaha yang ditujukan untuk merencanakan, menentukan harga, mempromosikan, dan mendistribusikan barang, jasa, ide kepada pasar sasaran agar dapat mencapai tujuan organisasi, sedangkan menjual adalah ilmu dan seni memengaruhi pribadi yang dilakukan oleh penjual untuk mengajak orang lain agar bersedia membeli barang atau jasa yang ditawarkan. Definisi lain juga dikemukakan oleh Nasruddin dan Ida (2014) menyatakan bahwa kunci untuk mencapai tujuan organisasi adalah pada penentuan kebutuhan dan keinginan dari pasar sasaran dan pada pemberian kepuasan yang diinginkan dengan lebih efektif dan efisien daripada para pesaing. Berikut adalah inti dari konsep pemasaran yaitu:

(1) Pemasaran atau tataniaga

(2) Kebutuhan

(3) Keinginan

(4) Permintaan

(5) Produk
Berdasarkan beberapa pendapat dapat diambil kesimpulan bahwa pemasaran adalah suatu aktifiatas dalam menyampaikan barang dan jasa kepada konsumen, dimana kegiatan tersebut dapat memenuhi kebutuhan dan kepuasan konsumen. Adapun tujuan dari pemasaran adalah untuk memahami keinginan dan kebutuhan konsumen agar produk atau jasa sesuai bagi konsumen sehingga produk atau jasa tersebut dapat terjual dengan sendirinya.

\section{Bauran Pemasaran}

Menurut Swastha dan Irawan dalam Mevita dan Heru (2013) Bauran pemasaran adalah kombinasi dari empat variabel atau kegiatan yang merupakan inti dari sistem pemasaran, yakni: produk, struktur harga, kegiatan promosi, dan sistem distribusi. Berdasarkan beberapa pendapat dapat diambil kesimpulan bahwa bauran pemasaran merupakan unsur dalam pemasaran yang saling berhubungan dan saling terkait sehingga suatu usaha dapat mencapai tujuan pemasaran yang efektif baik dalam memuaskan kebutuhan maupun keinginan konsumen.

Alma dan Hurriyati (2008) mengatakan bauran pemasaran terdiri dari $4 \mathrm{p}$ yaitu produk, harga, promosi, tempat. Berikut adalah penjelasan bauran pemasaran menurut beberapa pendapat para ahli:

\section{Produk (product)}

Alma dan Hurriyati (2008) menyatakan tingkatan Produk dalam merencanakan produk atau apa yang hendak ditawarkan ke pasar, para pemasar perlu berpikir melalui lima tingkatan produk dalam merencanakan penawaran pasar. Lima tingkatan produk tersebut terdiri dari:
a) Manfaat inti
b) Produk dasar
c) Produk yang diharapkan
d) Produk yang ditingkatkan
e) Produk yang potensial

Tjiptono ( 2015) menyatakan berdasarkan daya tahan atau berwujud tidaknya, produk diklasifikasikan ke dalam tiga kelompok yaitu:
a) Barang tidak tahan
b) Barang tahan lama
c) Jasa 


\section{Harga (price)}

Menurut Monroe dalam Diniaty (2014) menyatakan bahwa harga merupakan pengorbanan ekonomis yang dilakukan pelanggan untuk memperoleh produk atau jasa.

Menurut Alma (2008) produsen harus pandai menetapkan kebijaksanaan harga, tinggi atau rendahnya harga yang ditetapkan harus berpedoman pada :

a) Keadaan/ kualitas barang

b) Konsumen yang dituju, berpenghasilan tinggi, sedang, atau rendah, konsumen perkotaan atau pedesaan

c) suasana pasar.

Dari sudut pandang pemasaran, harga merupakan satuan moneter atau ukuran lainnya (termasuk barang dan jasa) yang ditukarkan agar memperoleh hak kepemilikan atau penggunaan suatu barang atau jasa. (Tjiptono, 2015).

\section{Promosi (promotion)}

Promosi merupakan salah satu faktor penentu keberhasilan suatu program pemasaran. Betapapun berkualitasnya suatu produk, bila konsumen belum pernah mendengarnya dan tidak yakin bahwa produk tersebut akan berguna bagi mereka, maka mereka tidak akan pernah membelinya.

Menurut Alma dan Hurriyati (2008) pengertian promosi adalah suatu bentuk komunikasi pemasaran. Yang merupakan aktivitas pemasaran yang berusaha menyebarkan informasi, mempengaruhi atau membujuk, dan atau mengingatkan pasar sasaran atas perusahaan dan produknya agar bersedia menerima, membeli dan loyal pada produk yang ditawarkan perusahaan yang bersangkutan.

Menurut Wasrob dan Ida (2014) Promosi terdiri atas lima komponen yaitu:
(1) Periklanan,
(2) Publisitas,
(3) Sales Promotion,
(4) Publik Relation,
(5) Direct Maketing.

\section{Tempat (place)}

Alma dan Hurriyati (2008) menyatakan untuk produk industri manufaktur place di artikan sebagai saluran distribusi (zero channel, two channel, dan multilevel channels), sedangkan untuk produk industri jasa, place diartikan sebagai tempat pelayanan jasa.

Definisi lain dikemukakan oleh Kotler dalam Martjiono (2010) tempat adalah berbagai kegiatan yang dilakukan perusahaan untuk membuat produknya mudah diperoleh dan tersedia untuk konsumen sasaran.

Alma dan Hurriyati (2008) menyatakan Pemilihan tempat atau lokasi memerlukan pertimbangan yang cermat terhadap beberapa faktor berikut :

a) Akses

b) Visibilitas

c) Lalu lintas

d) Tempat parkir yang luas dan aman

e) Ekspansi

f) Lingkungan

g) Persaingan

h) Peraturan pemerintah.

\section{Rumusan Masalah}

Berdasarkan latar belakang masalah yang telah dikemukakan, maka rumusan masalah dapat dirumuskan sebagai berikut :

1. Bagaimanakah bauran pemasaran UD. Betris?

\section{Tujuan Penelitian}

Tujuan penelitian ini adalah untuk mengetahui bauran pemasaran pada UD.Betris Di Kelurahan Meras Kecamatan Bunaken Kota Manado

\section{Manfaat Penelitian}

Penelitian ini diharapkan dapat memberikan manfaat antara lain :

1) Bagi peneliti, penelitian ini diharapkan dapat menambah wawasan dan pengetahuan peneliti tentang permasalahan yang dikaji serta merupakan salah satu syarat untuk memperoleh gelar Sarjana Pertanian di Fakultas Pertanian Universitas Sam Ratulangi. 
2) Bagi pengrajin bambu batik, penelitian ini diharapkan dapat menjadi sumbangan pemikiran dan bahan pertimbangan dalam menyusun bauran pemasaran yang lebih baik di masa yang akan datang untuk mengembangkan usahanya.

3) Bagi pihak lain, penelitian ini diharapkan dapat menjadi informasi serta wacana untuk menambah wawasan ilmu pengetahuan dan referensi untuk permasalahan yang sejenis pada masa yang akan datang.

\section{METODOLOGI PENELITIAN}

\section{Waktu dan Tempat Penelitian}

Penelitian ini dilaksanakan selama tiga Bulan yaitu dari Bulan November 2017 sampai Bulan Januari Tahun 2018 mulai dari persiapan penelitian sampai dengan penyusunan hasil penelitian. Tempat penelitian dilakukan di UD. Betris Kelurahan Meras Kecamatan Bunaken Kota Manado.

\section{Metode Pengumpulan Data}

Metode penelitian yang digunakan adalah studi kasus. Data yang digunakan adalah data primer dan data sekunder. Data primer meggunakan teknik wawancara berdasarkan daftar pertanyaan terhadap responden dan observasi di UD. Betris. Responden dalam penelitian ini yaitu pihak internal dan pihak eksternal. Pihak internal yaitu pemilik UD. Betris, sedangkan pihak eksternal yaitu Pemerintah setempat (Lurah dan Kepala Lingkungan 3) serta dari konsumen yaitu Dinas Koperasi, Dinas Sosial, Dinas Perindustrian dan Dinas Provinsi. Data sekunder diperoleh dari studi literatur yang berkaitan dengan data yang dibutuhkan sesuai fokus penelitian.

\section{Konsep Pengukuran Variabel}

Adapun variabel yang akan diukur dalam penelitian ini adalah bauran pemasaran yaitu :

1. Produk (product) berupa:
a) Jenis produk
b) Keunikan produk dan
c) Daya tahan dan mutu produk.

2. Harga (price) berupa
a) Kesesuaian harga dengan kualitas
b) Kebijakan harga
c) Variasi harga (murah, terjangkau, mahal).

3. Promosi (promotion) berupa
a) Promosi dengan menggunakan media sosial,
b) Promosi dengan pameran kerajinan

4. Tempat (place) berupa
a) Lokasi strategis
b) Kenyamanan tempat
c) Sarana transportasi memadai
d) Kemudahan menjangkau lokasi.

\section{Metode Analisis Data}

Metode analisis data adalah analisis deskriptif yakni mendeskripsikan pelaksanaan bauran pemasaran Kerajinan Bambu Batik di Kelurahan Meras Kecamatan Bunakaen Kota Manado. Berdasarkan penilaian responden yang dikategorikan jawaban dalam tiga tingkatan yaitu:
a. Skor $3=$ Baik
b. Skor $2=$ Ragu - ragu
c. Skor $1=$ Tidak baik
Penilaian bauran menggunakan pendekatan nilai rata - rata yang diperoleh dengan kategori sebagai berikut:
1 - 1,66 dikategorikan Tidak Baik
1,67 - 2,33 dikategorikan Ragu - ragu
2,34 - 3 dikategorikan Baik

pemasaran

\section{HASIL DAN PEMBAHASAN}

\section{Deskripsi Usaha}

Usaha kerajinan tangan dengan bahan baku bambu batik ini termasuk dalam golongan industri rumah tangga. Hal ini dapat dilihat pada jumlah tenaga kerja yang tidak lebih dari 4 orang, serta masih memiliki hubungan dalam keluarga. Selain itu juga dapat dilihat pada lokasi atau tempat produksinya yang dilakukan di rumah serta proses produksinya yang masih menggunakan alat yang sederhana. 
Letak usaha ini berada di Kelurahan Meras Kecamatan Bunaken Kota Manado. Usaha ini dirintis oleh Ibu Berta seorang pengrajin, Beliau menamakan usaha kerajinannya dengan nama UD. Betris. Ibu Berta memulai usahanya pada bulan oktober tahun 2015. Tahun 80-an Ibu Berta bersama ayahnya mengajarkan warga setempat untuk memainkan alat musik tradisional dan belajar membuat alat musik dari bahan baku bambu batik. Kerajinan yang pertama kali dibuat Ibu Berta yaitu alat musik yang bisa menghasilkan nada dengan bahan baku bambu batik. Kemudian berkembang sampai dengan sekarang Ibu Berta bisa membuat souvenir atau cenderamata dan miniatur rumah panggung dengan bahan baku bambu batik.

\section{Struktur Organisasi UD. Betris}

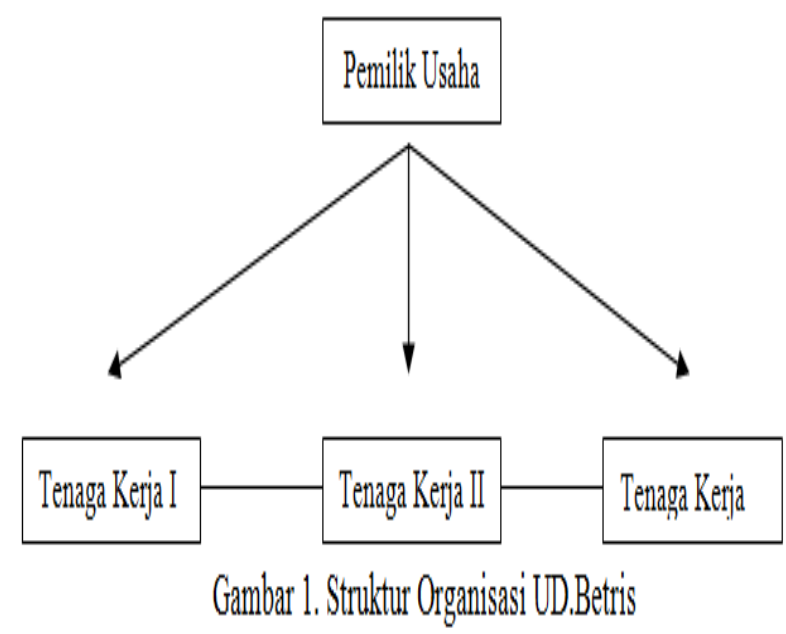

Di UD. Betris hanya terdapat tiga tenaga kerja, yang termasuk di dalamnya ibu berta selaku pemilik usaha/pengrajin dan di bantu oleh tiga orang tenaga kerja yang diberi upah berdasarkan hasil pembuatan produk. Tenaga kerja I ditugaskan untuk membelah atau memotong bambu. Tenaga kerja II mengamplas bambu dan tenaga kerja III mengelem produk, sedangkan Ibu Berta sendiri merangkai bambu batik menjadi sebuah produk yang unik dan bagus sekaligus melayani konsumen.

\section{Bauran pemasaran (Marketing Mix) di UD. Betris}

\section{Produk (product)}

UD. Betris menjual produk kerajinan tangan dengan bahan baku bambu batik yang memiliki ciri khas tersendiri yaitu terdapat bintik-bintik atau corak yang menyerupai batik. Produk ini adalah salah satu produk yang memiliki keunikan karena dilihat dari bahan bakunya yang memiliki ciri khas tersendiri serta produknya di buat dengan berbagai bentuk dan model mulai dari souvenir kecil seperti gantungan kunci berbentuk tetengkoreng, tas, ikan, dan souvenir besar berbentuk pot bunga, ceret, tempat tissue, dan bingkai foto. Ada juga miniatur alat musik saksofon, klarinet, rumah panggung, kursi dan meja, pesawat, kapal serta aksesoris seperti kalung dan anting untuk wanita. Produk UD. Betris ini bisa dipesan dengan bentuk dan modelnya sesuai selera konsumen. Selain itu produk ini juga memiliki kualitas daya tahan dan mutu produk yang baik. Berikut adalah Tabel 1 tentang persepsi rata - rata responden terhadap produk UD. Betris.

\begin{tabular}{lccccccc}
\multicolumn{1}{l}{ Tabel 1. Persepsi rata - rata responden terhadap produk UD. Betris } \\
\hline Produk & DK & DS & DP & DPR & L & KL & R \\
\hline Jenis produk & 3 & 3 & 3 & 3 & 3 & 3 & 3 \\
Keunikan & 3 & 3 & 3 & 3 & 3 & 3 & 3 \\
Daya tahan \& mutu & 3 & 3 & 3 & 3 & 2 & 3 & 2,83 \\
\hline Rata - rata & 3 & 3 & 3 & 3 & 2,6 & 3 & 2,93 \\
\hline
\end{tabular}

Keterangan:

$$
\begin{array}{ll}
\text { DK } & =\text { Dinas Koperasi } \\
\text { DS } & =\text { Dinas Sosial } \\
\text { DP } & =\text { Dinas Perindustrian } \\
\text { DPR } & =\text { Dinas Provinsi } \\
\text { L } & =\text { Lurah } \\
\text { KL } & =\text { Kepala Lingkungan III } \\
\text { R } & =\text { Rata }- \text { rata }
\end{array}
$$

Menurut Tabel 1 di atas Dari hasil penelitian yang di dapat berdasarkan persepsi rata - rata responden terhadap produk UD. Betris memperoleh nilai dengan rata - rata 2,93 yang termasuk dalam kategori baik. Sesuai dengan tanggapan konsumen banyak yang mengatakan produk di UD. Betris 
beranekaragam mulai dari bentuk, model serta desainnya pun unik dan menarik. Hal ini juga disetujui oleh Lurah dan Kepala Lingkungan 3 di Kelurahan Meras yang mengatakan produk UD. Betris ini memiliki keunikan tersendiri karena bahan bakunya yang bercorak seperti batik. Karena keunikannya produk ini selalu habis terjual di pameran atau acara yang diselenggarakan oleh dinas - dinas tertentu. Menurut Ibu Berta diantara jenis jenis produk tersebut yang paling banyak diminati oleh konsumen yaitu souvenir, karena banyak yang membeli souvenir untuk dijadikan oleh - oleh. Pada dasarnya banyak peminat dari produk UD. Betris ini karena produknya unik dan menarik akan tetapi produknya masih terbatas karena tenaga kerja di UD. Betris masih sangat sedikit.

Menurut tanggapan dari Lurah daya tahan dan mutu produk masih diragukan karena Lurah hanya melihat produk UD. Betris tapi tidak memiliki produknya. Berbeda dengan Dinas dan Kepala lingkungan 3 yang mengatakan bahwa UD. Betris sudah memberikan produk yang berkualitas dari segi daya tahan dan mutu produk. Hal ini dikarenakan UD. Betris menggunakan bahan baku yang berkualitas dalam proses produksi.

\section{Harga (price)}

Harga yang diberikan oleh UD. Betris berdasarkan tingkat kesulitan, dan bentuk/model dari masing - masing produk. UD. Betris memiliki harga yang bervariasi mulai dari harga paling murah, terjangkau, dan mahal. Produk yang termasuk dalam kategori murah yaitu seperti gantungan kunci yang bermacam - macam bentuk dan model serta anting wanita, untuk kisaran harganya mulai dari Rp. 10.000,00 - Rp. 35.000,00 yang harga produknya tergantung dari proses pembuatan yang tidak sulit dan hanya memerlukan waktu sehari untuk membuat produk. Produk yang termasuk kategori terjangkau yaitu kalung, tempat tisue, ceret dan bunga beserta pot, untuk kisaran harganya mulai dari Rp. 65.000,00 - Rp. 75.000,00 yang harga produknya tergantung dari proses pembuatan yang cukup sulit dan memerlukan waktu 2-3 hari untuk membuat produk . Produk yang termasuk dalam kategori mahal yaitu miniatur alat musik, miniatur rumah panggung dan kapal, untuk kisaran harganya mulai dari Rp. 125.000,00 Rp. 800.000,00 (harga sesuai ukuran) yang harga produknya tergantung dari proses pembuatan yang sulit sehingga memerlukan waktu 5-7 hari. Berikut adalah Tabel 2 persepsi rata - rata responden terhadap harga UD. Betris.

\begin{tabular}{lccccccc}
\multicolumn{1}{l}{ Tabel 2. Persepsi rata - rata responden terhadap harga UD. Betris } \\
\hline Harga & DK & DS & DP & DPR & L & KL & R \\
\hline Harga sesuai kualitas & 3 & 3 & 3 & 3 & 2 & 2 & 2,6 \\
Kebijakan harga & 3 & 3 & 3 & 3 & 2 & 2 & 2,6 \\
Variasi harga & 3 & 3 & 3 & 3 & 2 & 2 & 2,6 \\
\hline Rata - rata & 3 & 3 & 3 & 3 & 2 & 2 & 2,6 \\
\hline
\end{tabular}

Keterangan:

DK = Dinas Koperasi

DS $=$ Dinas Sosial

$\mathrm{DP} \quad=$ Dinas Perindustrian

$\mathrm{DPR}=$ Dinas Provinsi

$\mathrm{L} \quad=$ Lurah

$\mathrm{KL}=$ Kepala Lingkungan III

$\mathrm{R}=$ Rata - rata

Dari hasil penelitian yang didapat harga yang diterapkan UD. Betris bisa dikatakan sudah baik dalam penetapan harga dan kebijakan harga, karena dari hasil penelitian menurut persepsi rata - rata responden terhadap harga UD. Betris memperoleh nilai dengan rata - rata 2,6 yang termasuk dalam kategori baik.

Menurut tanggapan dari Dinas UD. Betris memiliki variasi harga dari produk yang paling murah, terjangkau, dan mahal. Harganya juga sudah sesuai dengan kualitas produk yang diberikan, karena bahan baku yang dipilih bagus, kuat, tidak mudah rapuh. Berbeda dengan tanggapan dari Lurah dan Kepala Lingkungan 3 yang mengatakan ragu - ragu karena tidak membeli produk UD. Betris. Menurut dari Dinas UD. Betris juga memberikan kebijakan harga kepada konsumennya yaitu diskon atau potongan harga 5\% jika pembelian dalam jumlah banyak. Dalam melayani pembayaran UD. Betris memberikan pelayanan yang terbaik dengan cepat dan mudah. 


\section{Promosi (promotion)}

Promosi yang di lakukan oleh UD. Betris yaitu promosi dengan menggunakan media sosial (facebook) dengan menampilkan gambar produk yang akan dijual dan testimoni produk yang sudah terjual serta proses pembuatan produk. Ibu Berta juga mempromosikan produknya lewat pameran pameran dan acara yang diselenggarakan oleh dinas - dinas terkait. Berikut adalah Tabel 3 persepsi rata - rata responden terhadap promosi UD. Betris.

Tabel 3. Persepsi rata - rata responden terhadap promosi UD.

\begin{tabular}{|c|c|c|c|c|c|c|c|}
\hline \multicolumn{8}{|c|}{ Betris } \\
\hline Promosi & DK & DS & DP & DPR & $\mathbf{L}$ & KL & $\mathbf{R}$ \\
\hline Media social & 3 & 1 & 1 & 3 & 2 & 3 & 2.16 \\
\hline Pameran kerjinan & 3 & 3 & 3 & 3 & 3 & 3 & 3 \\
\hline Rata - rata & 3 & 2 & 2 & 3 & 2.5 & 3 & 2.58 \\
\hline
\end{tabular}

Keterangan:

DK = Dinas Koperasi

DS = Dinas Sosial

$\mathrm{DP}=$ Dinas Perindustrian

DPR = Dinas Provinsi

$\mathrm{L} \quad=$ Lurah

$\mathrm{KL}=$ Kepala lingkungan III

$\mathrm{R}=$ Rata- Rata

Dalam penelitian ini menurut persepsi rata - rata responden terhadap promosi UD. Betris memperoleh nilai dengan rata - rata 2,58 yang termasuk dalam kategori baik. Menurut tanggapan dari Dinas Koperasi dan Dinas Provinsi yang sudah melihat promosi lewat facebook mengatakan bahwa tampilannya menarik akan tetapi dari Dinas Perindustrian dan Dinas Sosial mengatakan tampilannya kurang menarik. Menurut Dinas, Lurah dan Kepala Lingkungan 3 promosi UD. Betris lewat pameran sudah baik, karena banyak konsumen yang mengetahui produk UD. Betris lewat pameran sehingga banyak konsumen yang memesan lagi produknya.

\section{Tempat (place)}

UD. Betris berlokasi di Kelurahan Meras Kec. Bunaken Kota Manado, dengan waktu tempuh kira - kira 1 jam. Lokasi UD. Betris berada di Jln. Raya Meras Lingkungan 3. Untuk tempat pengambilan bahan baku sendiri tidak jauh dari lokasi UD. Betris. Berikut adalah Tabel 4 persepsi rata - rata responden terhadap tempat/lokasi UD. Betris.

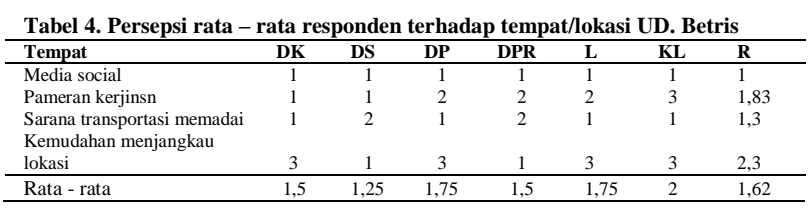

Keterangan:

DK = Dinas Koperasi

DS $=$ Dinas Sosial

$\mathrm{DP}=$ Dinas Perindustrian

DPR = Dinas Provinsi

$\mathrm{L} \quad=$ Lurah

$\mathrm{KL} \quad=$ Kepala Lingkungan III

$\mathrm{R} \quad=$ Rata - rata

Dalam penelitian ini berdasarkan persepsi rata - rata responden terhadap tempat/lokasi UD. Betris memperoleh nilai dengan rata - rata 1,5 yang termasuk dalam kategori tidak baik. Berdasarkan seluruh tanggapan konsumen lokasi tempat penjualan sekaligus pembuatan produk UD. Betris belum strategis, karena tempatnya jauh dari keramaian.

Menurut dari Dinas Koperasi dan Dinas Perindustrian sarana transportasi untuk ke lokasi UD. Betris sulit dijangkau, namun kesulitannya hanya pada malam hari karena susah untuk mendapatkan kendaraan umum jika lewat dari jam 8 malam dan susah untuk mendapatkan sinyal. Berbeda dengan Dinas Sosial dan Dinas Provinsi yang mengatakan ragu - ragu. Karena mereka memiliki kendaraan pribadi dan tidak tahu kalau ada angkot yang bisa sampai ke lokasi UD. Betris.

Menurut Dinas Sosial, Dinas Provinsi, Lurah dan Kepala lingkungan 3 mengatakan untuk pegi ke UD. Betris mudah dijangkau dengan transportasi tapi berbeda dengan Dinas Koperasi dan Dinas Perindustrian yang mengatakan tidak mudah, karena sulit mendapatkan kendaraan umum pada malam hari jika tidak memiliki kendaraan pribadi. Menurut keterangan dari ibu Berta saat ini produk UD. Betris sudah di jual di beberapa lokasi seperti Toko Miens dan Toko Dekranas. Hal tersebut dilakukan agar mempermudah konsumen untuk membeli 
produk UD. Betris. Hal ini sesuai dengan pendapat Kotler dalam Martjiono (2010) tempat adalah berbagai kegiatan yang dilakukan perusahaan untuk membuat produknya mudah diperoleh dan tersedia untuk konsumen sasaran.

Tempat/lokasi penjualan juga harus terasa nyaman agar supaya ketika konsumen datang berkunjung mereka bisa merasakan kenyamanan saat melihat atau membeli produk yang kita jual. Menurut tanggapan dari Dinas dan Lurah kenyamanan tempat di UD. Betris tidak nyaman. Hal itu dirasakan oleh mereka yang berkunjung langsung ke tempat UD. Betris yang mengatakan kalau tempatnya kecil dan masih bercampur dengan kegiatan produksi lainnya. Untuk mencapai sasaran tempat yang baik dapat dilakukan dengan jalan sebagai berikut: memperbanyak saluran distribusi, memperluas segmentasi atau cakupannya, menata penampilan tempat usaha, dan menggunakan cara penyampaian barang seefisien mungkin. Hal ini penting untuk mengendalikn persediaan dan penawaran.

Dari hasil penelitian bauran pemasaran (marketing mix) 7P yang diterapkan di UD. Betris menurut tanggapan konsumen dan Pemerintah setempat meliputi:

\begin{tabular}{|c|c|c|c|c|c|}
\hline \multicolumn{2}{|c|}{ Tabel 5.} & \multicolumn{4}{|c|}{$\begin{array}{l}\text { Bauran pemasaran yang diterapkan di UD. Betris berdasarkan } \\
\text { tanggapan konsumen dan tokoh masyarakat }\end{array}$} \\
\hline No & Aspek & Jumlah item & Jumlah skor & Rata - rata & Kategori \\
\hline 1 & Produk & 3 & 53 & 2,93 & Baik \\
\hline 2 & Harga & 3 & 48 & 2,6 & Baik \\
\hline 3 & Promosi & 2 & 31 & 2,58 & Baik \\
\hline \multirow[t]{2}{*}{4} & Tempat & 4 & 39 & 1,5 & Tidak baik \\
\hline & Rata- rata & & & 2,40 & Baik \\
\hline
\end{tabular}

Secara umum Tabel 5 menunjukkan bahwa bauran pemasaran UD. Betris dikategorikan sudah baik, karena dari empat aspek tempat yang belum diterapkan dengan baik yang disebabkan tidak strategisnya tempat penjualan.

\section{KESIMPULAN DAN SARAN}

\section{Kesimpulan}

Bauran pemasaran secara umum sudah baik penerapannya di UD. Betris karena dari ke empat aspek hanya aspek tempat yang tidak baik penerapannya di UD. Betris.

\section{Saran}

1. Bagi Pemerintah Kota Manado

Untuk dapat memberikan bantuan modal agar bisa mengembangkan usaha kerajianan bambu ini menjadi lebih besar serta dapat memfasilitasi perkembangan industri kerajinan bambu yang ada di Meras ini terutama untuk mesin dan alat dalam proses produksi dan menyediakan sarana atau tempat untuk memasarkan produk - produk kerajinan bambu.

2. Bagi pengusaha kerajinan bambu

Perlu diperhatikan kembali bauran pemasaran di UD. Betris agar bisa mencapai tujuan pemasaran yang efektif baik dalam memuaskan kebutuhan maupun keinginan konsumen terhadap produk yang ditawarkan. hal-hal yang perlu diperhatikan yaitu:

a. Perlu adanya penambahan tenaga kerja yang ahli dalam pembuatan produk sehingga proses pembuatan produk bisa lebih tepat waktu.

b. Mencari tempat yang strategis dan mudah di jangkau oleh konsumen

\section{DAFTAR PUSTAKA}

Adkha, N. 2016. Pesepsi Konsumen Terhadap Warung Makan Indomie Di Wilayah Mrican. Fakultas Teknik Universitas Negeri Yogyakarta. Skripsi.

Alma, B. dan Ratih, H. 2008. Manajemen Corporate dan Strategi Pemasaran Jasa Pendidikan. Penerbit Alfabeta. Bandung

Asri, W. dan Tri, S. 2007. Pengaruh Bauran Pemasaran Jasa Terhadap Keputusan Pembelian Produk Klinik Kecantikan Nanisa Beauty \& Dental Clinic Di Sidoarjo. Jurnal Pendidikan Ekonomi Tata Niaga. Surabaya. Vol. 3. No. 4, Hal. 46-52. 
Diniaty, D. dan Agusrinal. 2014. Perancangan Strategi Pemasaran Pada Produk Anyaman Pandan. Jurnal Teknologi Dan Industri. Riau. Vol 11. No. 2, Hal. 175-184.

Febrianto, H. 2008. Strategi Pemasaran Pada Mini Market Ahad Dalam Peningkatan Volume Penjualan. Fakultas Syariah dan Hukum Universitas Islam Negeri Syarif Hidayatullah. Skripsi

Hermawan, H. 2015. Analisis Pengaruh Bauran Pemasaran Terhadap Keputusan, Kepuasan Dan Loyalitas Konsumen Dalam Pembelian Roti Ceria Di Jember. Jurnal Manajemen Dan Bisnis Indonesia. Jember. Vol. 1 No. 2, Hal 61-73

Iskandar, K. dan Wilan, A. 2014. Pengaruh Strategi Pemasaran Terhadap Penjualan Batubara Pada PT. Cahaya Mantingan Nusantara Jakarta. Jurnal Ekonomi. Jakarta. Vol. 7 No. 1, Hal. 24-34

Kereh, D. 2017. Strategi Pengembangan Industri Rumah Tangga Kerajinan Bambu Di Kinilow Kecamatan Tomohon Utara Kota Manado. Fakultas Pertanian Universitas Sam Ratulangi. Skripsi

Martjiono, R. 2010. Analisa Pengaruh Bauran Pemasaran (7P) Terhadap Keputusan Pembelian Di Rumah Makan Kakkk, Ayam Geprek. Jurnal Ekonomi Manajemen Perhotelan. Surabaya. Vol. 3. No. 8, Hal. 78-90.

Mevita, A. dan Heru, S. 2013. Pengaruh Bauran Pemasaran Terhadap Kepuasan Konsumen. Jurnal Ilmu dan Riset Manajemen. Surabaya. Vol. 2. No. 9, Hal. 49-61.
Nasruddin Wasrob, dan Ida. 2014. Manajemen Agribisnis. Universitas Terbuka. Tanggerang Selatan.

Nirmala, S. dkk. 2013. Strategi Pemasaran Agroindustri Keripik Tempe Di Desa Buluh Rampai Kecamatan Seberida Kabupaten Indragiri Hulu. Jurnal Agribisnis. Vol. 2. No. 7, Hal. 97-114.

Rahmat, R. 2012. Analisis Strategi Pemasaran Pada PT. Koko Jaya Prima Makassar. Fakultas Ekonomi Dan Bisnis UNHAS. Skripsi

Tjiptono, F. 2015. Strategi Pemasaran, Edisi 4. CV ANDI. Yogyakarta.

Tri, S. Kerajinan Batik Kayu. http://goborobudur.com/2017/05/01/gall ery-bw-craft-kerajinan-batik-di-ataskayu/. 1 May 2017.

Utami, A. 2016. Pengaruh Bauran Pemasaran Terhadap Keputusan Pembelian Konsumen Di Minimarket Kopma. Fakultas Ekonomi Universitas Negeri Yogyakarta. Skripsi.

Utami, S. 2013. Pengaruh Bauran Pemasaran Terhadap Keputusan Pembelian Gula Pasir Oleh Konsumen Rumah Tangga Pada Pasar Swalayan. Fakultas Pertanian Universitas Sebelas Maret. Skripsi.

Wijaya, T. 2013. Metodologi Penelitian Ekonomi Dan Bisnis. Edisi Pertama. Graha Ilmu. Yogyakarta.

Wijayanti, R. dan Kertati . 2009. Pengaruh Bauran Pemasaran Jasa terhadap Loyalitas Anggota pada KJKS BMT Bina Ummat Sejahtera Lasem Cabang Kudus. Jurnal Analisis Manajemen. Jakarta. Vol. 3. No. 7, Hal. 80-101 
Yusuf, M. 2007. Analisis Kepuasan

Konsumen Terhadap Bauran

Pemasaran. Fakultas Ekonomi Institut

Pertanian Bogor. Skripsi. 